\title{
Analysis of Laptop Users Purchase Behaviour: A Case of Kathmandu, Nepal
}

\author{
Anjay Kumar Mishra* \& P. S. Aithal** \\ *Post Doctoral Research Scholar, Srinivas University, India and Associate Professor, Madan \\ Bhandari Memorial Academy Nepal, Urlabari3, Morang, Nepal \\ OrcidID: 0000-0003-2803-4918; Email: anjaymishra2000@ gmail.com \\ ***Professor, College of Management \& Commerce, Srinivas University, Mangalore, India \\ OrcidID: 0000-0002-4691-8736; E-mail: psaithal@gmail.com
}

Area/Section: Business Management.

Type of the Paper: Analytical Marketing Research.

Type of Review: Peer Reviewed as per $|\mathrm{C}| \mathrm{O}|\mathrm{P}| \mathrm{E} \mid$ guidance.

Indexed in: OpenAIRE.

DOI: https://doi.org/10.5281/zenodo.4966112

Google Scholar Citation: IJMTS

\section{How to Cite this Paper:}

Mishra, Anjay Kumar, \& Aithal, P. S., (2021). Analysis of Laptop Users Purchase Behaviour: A Case of Kathmandu, Nepal. International Journal of Management, Technology, and Social Sciences (IJMTS), 6(1), 226-240. DOI: https://doi.org/10.5281/zenodo.4966112.

International Journal of Management, Technology, and Social Sciences (IJMTS) A Refereed International Journal of Srinivas University, India.

CrossRef DOI: https://doi.org/10.47992/IJMTS.2581.6012.0142

(C) With Author.

\section{(c) (1) (9)}

This work is licensed under a Creative Commons Attribution-Non-Commercial 4.0 International License subject to proper citation to the publication source of the work.

Disclaimer: The scholarly papers as reviewed and published by the Srinivas Publications (S.P.), India are the views and opinions of their respective authors and are not the views or opinions of the SP. The SP disclaims of any harm or loss caused due to the published content to any party. 


\title{
Analysis of Laptop Users Purchase Behaviour: A Case of Kathmandu, Nepal
}

\author{
Anjay Kumar Mishra* \& P. S. Aithal** \\ *Post Doctoral Research Scholar, Srinivas University, India and Associate Professor, Madan \\ Bhandari Memorial Academy Nepal, Urlabari3, Morang, Nepal \\ OrcidID: 0000-0003-2803-4918; Email: anjaymishra2000@ gmail.com \\ ***Professor, College of Management \& Commerce, Srinivas University, Mangalore, India \\ OrcidID: 0000-0002-4691-8736; E-mail: psaithal@gmail.com
}

\begin{abstract}
Purpose: The laptop market is highly competitive in Nepal. Kathmandu being the capital city with a high number of laptop users, several brands of laptops are available. The paper aims to find out the dependency between brand and gender, age, marital status, occupation, education, income, and other external factors using inferential statics.

Design/Methodology/Approach: The study is based on a questionnaire survey from 120 users from a different class. Chi-square and one-way ANOVA analysis tests are performed to test for a relationship between the importance of several independent factors and respondents' gender, age, occupation, income, and education level.

Findings/Result: Significant influence of age was not on brand preference for laptops in less than of $10 \%$ significance. Brand preference of laptop is significantly dependent on monthly income. Educational qualification, Brand image, Features, Configuration, Audio quality, Video quality, Price, Convenience of service, Scheme and offers, Advertisement, Family, and Friend influence are not significant for brand preference of laptops. The hypothesis testing showed that brand preference has a significant relationship only with occupation, age, and monthly income.
\end{abstract}

Originality/Value: It is a significant research for buyers and sellers of laptops in Nepal using the inferential model.

Paper Type: Analytical Marketing Research.

Keywords: Age, Income, Brand, Features, Factors, Laptop, Purchase behaviour

\section{INTRODUCTION:}

A decade ago, laptop market was not so competitive. Very few brands were available in the market and the numbers of users were also very low. Compared to desktop computers the users of Laptops were low, as the prices were very high. But today Laptops are available from Rs 15,000 to Rs 250,000. The variation in price is because of brand name, features, accessories, etc. The laptop has become very common to people and every work has become almost impossible without Laptop. It's a necessity rather than a luxury.

Laptop using culture is increasing in the city and along with that the availability of various brands as well. Various low-cost Laptops from China and India are currently available in the market. But the price is not only the factor that people consider while purchasing a laptop. There are some buyers who are influenced by the price while some are influenced by the quality, technology, or brand itself. Different consumers have different attitudes and perceptions regarding the different brands. Likewise, the age and income of consumers also determine the buying behavior for a specific brand.

Branding is an important aspect of marketing a product. It is perhaps, the most distinctive skill of professional marketers which helps them to create, maintain protect and enhance brands of their product and services. According to Mishra and Aithal (2021) [1] and Sah and Mishra (2020) [2], Kathmandu buyers are not much price sensitive as they are reluctant to switch their bards due to price as they wait for preferred brands in case of shortage of preferred brand. Users relied on the proven technology of laptops. Even offers to attack them whereas Sah and Mishra (2020) [2] stated brand is reflected mainly by features, audio quality, and video quality which might not be applicable in all case and professional 
may be neutral. Even a study has shown influencing factors and strategy and need of segmentation are different, not same of other sectors buyer as of laptop users as evidenced from Mishra et al. (2019) [3] and Mishra and Sharestha, (2019) [4].

Brand preference is a definite expression of a positive attitude. This study helps in knowing the customer who prefers a brand and gives important insight to the marketer to develops a marketing strategy. Along with this, the marketers can also get acquainted with valuable information regarding the brand attitude, likes and dislikes of customers regarding a brand. Analysis of customer behavior through preference patterns is very much essential for today's competitive, changing, and globalized market. The study of present status of the laptop market in Kathmandu valley, which in fact would be useful for organizations dealing with laptops. Outcomes of the research would help the existing players to analyze their current marketing policy and reevaluate if necessary. And the new firms looking for proper marketing policy and structure may be benefited from the study.

\section{OBJECTIVES :}

The general objective of the study is to find the out the dependency between brand and gender, age, marital status, occupation, education, income and other external factors using inferential statics.

\section{LITERATURE REVIEW :}

\section{Conceptual Framework}

\section{Independent Variables}

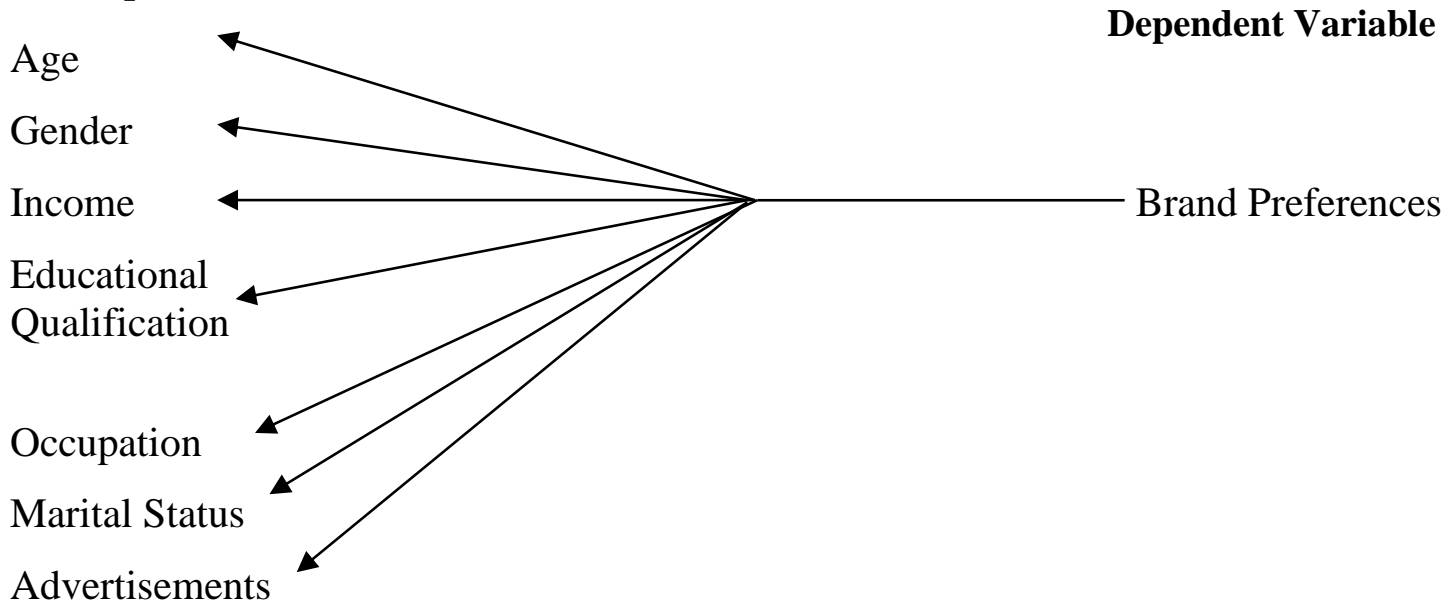

Fig. 1: Variables taken in to consideration

Figure 1 shows all independent variables which are influencing the dependent variable [5]. For this study purpose Hypothesis was developed and assured including other probable variables also e.g. extended service warranty, add on software packages, friends and family, schemes and offers, convenience of service, price, video quality, audio quality, configuration, features, brand image, and so on. The consumers purchasing pattern and characteristics such as age, gender, occupation, education, and monthly income are also taken for study so as to find out whether or not they are correlated with brand preference. Further, the research identifies the profiles of the different available brands of laptops, identifies the major media for advertisement [6].

It is found that several research and studies have been made to identify and analyze the brand preference of laptops in international scenarios [7]. Several journals/articles are written and several types of research have been published regarding branding. In spite of all marketing implications of brand preference, however, no research study has been carried out so far to analyze the consumer's brand preference for laptops in Kathmandu. So, this study is therefore conducted mainly to analyze the consumers' brand preference of laptops for the Kathmandu market.

\section{RESEARCH METHODOLOGY :}

\subsection{Sampling:}


The sample size of 120 respondents seems very small in response to the targeted population of laptop users, efforts have been made in order to make the sample represent the targeted population and the literature also stated that more than 30 respondents are enough for perception based study. The members of the population included in the sample are therefore, from different age group, income group, and booth sex, male and female of Kathmandu Valley.

\subsection{Data Collection:}

The schedule questionnaire has also been conducted as the main source of data collection. For the sake of designing the content of questionnaire, suggestions, and ideas have been collected from experienced scholars. In this process of data collection, Schedule survey of questionnaires was made to the respondents.

\subsection{Data Analysis:}

Inferential Analysis was done. Hypothesis Testing: A hypothesis is a statement about the relationship between two or more which needs to be investigated for the truth. If the relationship between two or more variables acts as hypothesis predicts, then the hypothesis is supported.

One Way ANOVA: One way ANOVA analysis tests are performed to test for a relationship between the importance of several independent factors and respondents' gender, age, occupation, income, and education level at $95 \%$ of confidence level.

\section{RESULTS AND DISCUSSION :}

\subsection{Character of Consumer in Response to Brand Preference:}

\subsubsection{Gender, Marital Status, and Occupation Response in Brand Preference}

Using $\chi 2$ test relation of Gender, Marital status, and occupation for brand preference have been analyzed in Table 1 with the following hypothesis.

H0: nonexistence of a significant association between gender and brand preference of laptop.

Ha: existence of a significant association between gender and brand preference of laptop.

H0: nonexistence of a significant association between marital status and brand preference of laptop.

Ha: existence of a significant association between marital status and brand preference of laptop.

H0: nonexistence of a significant association between occupation and brand preference of laptop.

Ha: existence of a significant association between occupation and brand preference of laptop.

Table 1: Brand Preference in Relation to Gender, Marital Status, and Occupation

\begin{tabular}{|c|c|c|c|c|c|c|c|c|c|}
\hline \multirow{2}{*}{$\begin{array}{l}\text { Brand Preference in } \\
\text { response to }\end{array}$} & \multicolumn{3}{|c|}{ Gender } & \multicolumn{3}{|c|}{ Marital status } & \multicolumn{3}{|c|}{ Occupation } \\
\hline & Value & Df & $\begin{array}{l}\text { Asymp. Sig. } \\
\text { (2-sided) }\end{array}$ & Value & Df & $\begin{array}{l}\text { Asymp. Sig. (2- } \\
\text { sided) }\end{array}$ & Value & Df & $\begin{array}{l}\text { Asymp. Sig. (2- } \\
\text { sided) }\end{array}$ \\
\hline Pearson Chi-Square & $4.115^{\mathrm{a}}$ & 7 & .766 & $11.261^{\mathrm{a}}$ & 7 & .128 & $34.708^{a}$ & 21 & .030 \\
\hline Likelihood Ratio & 4.643 & 7 & .703 & 12.889 & 7 & .075 & 37.404 & 21 & .015 \\
\hline $\begin{array}{l}\text { Linear-by-Linear } \\
\text { Association }\end{array}$ & 2.287 & 1 & .130 & 3.814 & 1 & .051 & 1.776 & 1 & .183 \\
\hline $\mathrm{N}$ of Valid Cases & 120 & & & 120 & & & 120 & & \\
\hline
\end{tabular}

Table 1 shows that the sig. value (p-value) (0.776) for gender is greater than Alfa value (0.05). This implies the acceptance of the null hypothesis, that gender not significant for brand preference of laptops 
among Kathmandu users at 95\% confidence level. Similarly, the sig. value (p-value) (0.128) for marital status is greater than Alfa value (0.05) which accepts the null hypothesis to illustrate that marital status does not have significance in brand preference of laptop statically. However, the sig. value (p-value) (0.030) for occupation is less than Alfa value (0.05) which means rejection of null hypothesis resulting into significant relation between occupation and brand preference of laptop statically. Gender and Marriage does not make much sense in professional life and the laptop is a symbol of professionalism in recent days. The profession is an extension of Occupation mixing with dedication, specialized knowledge, professional association membership, etc. which might be highly influenced by specialized technology and laptop reflects the adoption of technology resulting in higher productivity.

\subsubsection{Influence of Age on Brand Preference}

Age is an important factor for determining our mental construct level which regulates our behavior, preference and liking. But does age also play a vital role in choosing our laptop brand which is tested using one way ANOVA Analysis as shown in table 2.

H0: nonexistence of a significant association between Age and brand preference of laptop.

Ha: existence of a significant association between Age and brand preference of laptop.

Table 2: Role of Age on Brand Preference of Laptop

\begin{tabular}{|l|l|l|l|}
\hline Descriptive & & \\
\hline $\begin{array}{l}\text { Most Preferred Laptop } \\
\text { Brand }\end{array}$ & N & Mean & $\begin{array}{l}\text { Std. } \\
\text { Deviation }\end{array}$ \\
\hline & & & \\
\hline $15-30$ & 81 & 3.65 & 2.20 \\
\hline $30-45$ & 32 & 2.59 & 2.06 \\
\hline $45-60$ & 7 & 3.14 & 1.77 \\
\hline Total & $\mathbf{1 2 0}$ & $\mathbf{3 . 3 4}$ & $\mathbf{2 . 1 8}$ \\
\hline
\end{tabular}

\section{ANOVA}

\begin{tabular}{|l|l|l|l|l|l|}
\hline $\begin{array}{l}\text { Most Preferred Laptop } \\
\text { Brand }\end{array}$ & $\begin{array}{l}\text { Sum of } \\
\text { Squares }\end{array}$ & df & $\begin{array}{l}\text { Mean } \\
\text { Square }\end{array}$ & F & Sig \\
\hline Between Groups & 26.09 & 2.00 & 13.05 & 2.84 & 0.062 \\
\hline Within Groups & 536.90 & 117.00 & 4.59 & & \\
\hline Total & $\mathbf{5 6 2 . 9 9}$ & $\mathbf{1 1 9 . 0 0}$ & & & \\
\hline
\end{tabular}

Table 2 shows that the sig. value (p-value) (0.062) for age is greater than Alfa value (0.05). So, null hypothesis should be accepted disconfirming the role of Age on brand preference of laptop statically at $5 \%$ loss of accuracy. But at $10 \%$ significance level the result is reverse as null hypothesis seems to be rejected, that there is significant role of age on brand preference of laptop. Age can play role but age determined by intellect of individuals in case of laptop brand selection that may cause not be influenced at 5 percent level of assurance while it increases to $10 \%$ it gave space to introduce the part of intellect which depends upon Age.

\subsubsection{Educational Qualification and Brand Preference}

Education is the modification of behavior through mental and physical training. Individual's level of education determines the way of thinking and regulating the self and reaction in the situation. Education makes people universal thinker and free from objected decision as they make decision at level of value rather than attitude if they have higher education of the level. The impact of level of education on laptop brand preference can be seen from table 3 .

H0: nonexistence of significant association between Educational Qualification and Brand Preference of laptop. 
Ha: existence of significant association between Educational Qualification and Brand Preference of laptop.

Table 3: Relationship between educational qualification and brand preference

\begin{tabular}{|l|l|l|l|}
\hline $\begin{array}{l}\text { Most Preferred Laptop } \\
\text { Brand }\end{array}$ & & & \\
\hline Educational Qualification & $\mathrm{N}$ & Mean & $\begin{array}{l}\text { Std. } \\
\text { Deviation }\end{array}$ \\
\hline Below SLC & 2 & 5.00 & 5.66 \\
\hline $10+2$ & 21 & 3.33 & 1.85 \\
\hline Bachelors Degree & 51 & 3.27 & 2.27 \\
\hline Masters Degree \& Above & 46 & 3.35 & 2.10 \\
\hline Total & $\mathbf{1 2 0}$ & $\mathbf{3 . 3 4}$ & $\mathbf{2 . 1 8}$ \\
\hline
\end{tabular}

ANOVA

\begin{tabular}{|l|l|l|l|l|l|}
\hline $\begin{array}{l}\text { Most Preferred Laptop } \\
\text { Brand }\end{array}$ & & & & & \\
\hline & $\begin{array}{l}\text { Sum of } \\
\text { Squares }\end{array}$ & df & $\begin{array}{l}\text { Mean } \\
\text { Square }\end{array}$ & F & Sig \\
\hline Between Groups & 5.73 & 3 & 1.91 & 0.40 & 0.755 \\
\hline Within Groups & 557.26 & 116 & 4.80 & & \\
\hline Total & $\mathbf{5 6 2 . 9 9}$ & $\mathbf{1 1 9}$ & & & \\
\hline
\end{tabular}

Table 3 shows that the sig. value (p-value) (0.755) for educational qualification is greater than Alfa value (0.05). It shows acceptance of the null hypothesis. It means level of educational qualification is impact less in case of brand preference of laptop. This result seems surprising but it may be as respondents assume Nepal being developing country jobs are not available so people take higher education avoid earlier unemployment which might not develop behavior and wisdom by education as we know education without environment and experience might not be functional. So, people after education should have experience and environment otherwise, they take decision without applying their rational using snapshot which is not enough in the VUCA world.

\subsubsection{Monthly Income and Brand Preference}

Level of income determines standard of leaving of individuals. How much you earn determines by how much you spend which regulates what could be your need. Monthly income determines affordability and creates needs as it is our ability to pay. Its impact for laptop brand preferences has been checked table 4.

H0: nonexistence of significant association between Monthly Income and Brand Preference of laptop. Ha: existence of significant association between Monthly Income and Brand Preference of laptop.

Table 4: Relationship between Monthly Income and Brand Preference

\begin{tabular}{|l|l|l|l|l|}
\hline $\begin{array}{l}\text { Most Preferred Laptop } \\
\text { Brand }\end{array}$ & N & Mean & $\begin{array}{l}\text { Std. } \\
\text { Deviation }\end{array}$ \\
\hline Monthly Income & 56 & 3.25 & 2.35 \\
\hline Below 25000 & 45 & 3.22 & 2.07 \\
\hline $25000-50000$ & 16 & 4.06 & 1.95 \\
\hline $50000-100000$ & 3 & 3.00 & 1.73 & \\
\hline Above 100000 & $\mathbf{1 2 0}$ & $\mathbf{3 . 3 4}$ & $\mathbf{2 . 1 8}$ & \\
\hline Total & \multicolumn{5}{|l}{} & \\
\hline ANOVA & $\begin{array}{l}\text { Most Preferred Laptop } \\
\text { Brand }\end{array}$ & & & \\
\hline
\end{tabular}




\begin{tabular}{|l|l|l|l|l|l|} 
& $\begin{array}{l}\text { Sum of } \\
\text { Squares }\end{array}$ & df & $\begin{array}{l}\text { Mean } \\
\text { Square }\end{array}$ & F & Sig \\
\hline Between Groups & 9.776 & 3.000 & 3.259 & 2.940 & 0.0438 \\
\hline Within Groups & 553.215 & 116.000 & 4.769 & & \\
\hline Total & 562.992 & 119.000 & & & \\
\hline
\end{tabular}

Table 4 shows that the sig. value (p-value) (0.0438) for monthly income is less than Alfa value $(0.05)$ which guides us to say that monthly income influences us to select brand of laptop. Which is obvious as monthly income depending upon occupation and the occupational influence has been seen strongly through chi-square.

\subsubsection{Relationship between Brand Preferences of Laptop and Brand Image}

In commercial world, Brand Image provides introduction to the products and service and the company. It is intangible but guarantee of tangible profit that is why companies do not hesitate to spend for creating image of their brand [8]. Is it necessary for laptop market? It has been checked in table 5. H0: nonexistence of significant association between brand image and Brand Preference of laptop. Ha: existence of significant association between brand image and Brand Preference of laptop.

Table 5: Relationship between Brand Preferences of laptop and Brand Image

\begin{tabular}{|c|c|c|c|c|c|}
\hline \multicolumn{4}{|l|}{ Descriptives } & \multirow{2}{*}{ 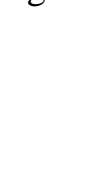 } & \\
\hline \multicolumn{4}{|l|}{$\begin{array}{lll}\text { Most } & \text { Preferred } & \text { Laptop } \\
\text { Brand } & & \end{array}$} & & \\
\hline Brand Image & $\mathrm{N}$ & Mean & $\begin{array}{l}\text { Std. } \\
\text { Deviation }\end{array}$ & & \\
\hline Very Bad & 3 & 1.667 & 1.155 & & \\
\hline $\mathrm{Bad}$ & 7 & 3.143 & 2.193 & & \\
\hline Average & 29 & 3.448 & 2.245 & & \\
\hline Good & 48 & 2.958 & 2.183 & & \\
\hline Very Good & 33 & 4.000 & 2.062 & & \\
\hline Total & 120 & 3.342 & 2.175 & & \\
\hline \multicolumn{6}{|l|}{ ANOVA } \\
\hline \multicolumn{6}{|l|}{$\begin{array}{l}\text { Most Preferred Laptop } \\
\text { Brand }\end{array}$} \\
\hline & $\begin{array}{l}\text { Sum of } \\
\text { Squares }\end{array}$ & $\overline{d f}$ & $\begin{array}{l}\text { Mean } \\
\text { Square }\end{array}$ & $\mathrm{F}$ & Sig \\
\hline Between Groups & 30.379 & 4.000 & 7.595 & 1.640 & 0.169 \\
\hline Within Groups & 532.613 & 115.000 & 4.631 & & \\
\hline Total & 562.9917 & 119 & & & \\
\hline
\end{tabular}

Table 5 shows that the sig. value (p-value) (0.169) for brand image is greater than Alfa value (0.05) which means significance of brand image cannot be confirmed. As people buy laptop depending upon need which depends on occupation not much on the values of brand image as may be monthly income might not be sufficient for affording the stated brand.

\subsubsection{Brand Preferences of Laptop and Features}

H0: nonexistence of significant association between features and Brand Preference of laptop.

Ha: existence of significant association between features and Brand Preference of laptop.

Table 8: Relationship between brand preferences of laptop and features

\begin{tabular}{|l|l|l|l|}
\hline Descriptives \\
\hline $\begin{array}{l}\text { Most Preferred Laptop } \\
\text { Brand }\end{array}$ & & & \\
\hline
\end{tabular}

Anjay Kumar Mishra, et al, (2021); www.srinivaspublication.com 


\begin{tabular}{|c|c|c|c|c|c|}
\hline Features & $\mathrm{N}$ & Mean & \begin{tabular}{|l} 
Std. \\
Deviation \\
\end{tabular} & & \\
\hline Very Bad & - & - & - & & \\
\hline $\mathrm{Bad}$ & 10 & 3.500 & 1.958 & & \\
\hline Average & 21 & 3.381 & 2.539 & & \\
\hline Good & 58 & 3.121 & 2.145 & & \\
\hline Very Good & 31 & 3.677 & 2.088 & & \\
\hline Total & 120 & 3.342 & 2.175 & & \\
\hline \multicolumn{6}{|l|}{ ANOVA } \\
\hline \multicolumn{6}{|c|}{$\begin{array}{l}\text { Most Preferred Laptop } \\
\text { Brand }\end{array}$} \\
\hline & $\begin{array}{l}\text { Sum of } \\
\text { Squares }\end{array}$ & $\mathrm{df}$ & $\begin{array}{l}\text { Mean } \\
\text { Square }\end{array}$ & $\mathrm{F}$ & Sig \\
\hline Between Groups & 6.610 & 3 & 2.203 & 0.459 & 0.711 \\
\hline Within Groups & 556.382 & 116 & 4.796 & & \\
\hline Total & 562.992 & 119 & & & \\
\hline
\end{tabular}

Table 8 shows that the sig. value (p-value) (0.711) for features is greater than Alfa value (0.05). So it can be understood that features of laptop is not factors as of user perception which influence brand preference as buyers assure features depends on budget which depends on monthly income. So it's monthly income that assures all covering occupational needs of laptop.

\subsubsection{Brand preferences of laptop and configuration}

H0: nonexistence of significant association between configuration and Brand Preference of laptop.

Ha: existence of significant association between configuration and Brand Preference of laptop.

Table 9: Brand preferences of laptop and configuration

\begin{tabular}{|c|c|c|c|c|c|}
\hline \multirow{2}{*}{\multicolumn{4}{|c|}{ Descriptives }} & & \\
\hline & & & & & \\
\hline \multicolumn{4}{|l|}{$\begin{array}{lll}\text { Most Preferred Laptop } \\
\text { Brand }\end{array}$} & & \\
\hline Configuration & $\mathrm{N}$ & Mean & $\begin{array}{l}\text { Std. } \\
\text { Deviation }\end{array}$ & & \\
\hline Very Bad & 2 & 4.000 & 1.414 & & \\
\hline $\mathrm{Bad}$ & 7 & 3.286 & 2.138 & & \\
\hline Average & 34 & 3.235 & 1.955 & & \\
\hline Good & 52 & 3.519 & 2.380 & & \\
\hline Very Good & 25 & 3.080 & 2.178 & & \\
\hline Total & 120 & 3.342 & 2.175 & & \\
\hline \multicolumn{6}{|l|}{ ANOVA } \\
\hline \multicolumn{6}{|l|}{$\begin{array}{l}\text { Most Preferred } \text { Laptop } \\
\text { Brand }\end{array}$} \\
\hline & $\begin{array}{l}\text { Sum of } \\
\text { Squares }\end{array}$ & $\mathrm{df}$ & $\begin{array}{l}\text { Mean } \\
\text { Square }\end{array}$ & $\mathrm{F}$ & Sig \\
\hline Between Groups & 4.625 & 4 & 1.156 & 0.238 & 0.916 \\
\hline Within Groups & 558.367 & 115 & 4.855 & & \\
\hline Total & 562.992 & 119 & & & \\
\hline
\end{tabular}

Table 9 shows that the sig. value (p-value) (0.916) for configuration is greater than Alfa value (0.05). Configuration can be signified as a determinates of brand preferences as buyers assume that in IT every day new things are coming only few things are applicable for us why should we bothered about that as we are going to operate only that thing which made us comfortable to performs as of our past experiences. 


\subsubsection{Brand Preferences of Laptop and Audio Quality}

H0: nonexistence of significant association between brand preferences of laptop and audio quality. Ha: existence of significant association between brand preferences of laptop and audio quality.

Table 10: Brand preferences of laptop and audio quality

\begin{tabular}{|c|c|c|c|c|c|}
\hline \multirow{2}{*}{\multicolumn{4}{|c|}{ Descriptives }} & & \\
\hline & & & & & \\
\hline \multicolumn{4}{|l|}{$\begin{array}{lll}\text { Most Preferred } & \text { Laptop } \\
\text { Brand } & & \\
\end{array}$} & & \\
\hline Audio Quality & $\mathrm{N}$ & Mean & $\begin{array}{l}\text { Std. } \\
\text { Deviation }\end{array}$ & & \\
\hline Very Bad & 6 & 4.667 & 2.658 & & \\
\hline $\mathrm{Bad}$ & 11 & 2.909 & 2.386 & & \\
\hline Average & 32 & 3.188 & 2.250 & & \\
\hline Good & 47 & 3.213 & 2.032 & & \\
\hline Very Good & 24 & 3.667 & 2.160 & & \\
\hline Total & 120 & 3.342 & 2.175 & & \\
\hline \multicolumn{6}{|l|}{ ANOVA } \\
\hline \multicolumn{6}{|l|}{\begin{tabular}{lll|} 
Most & Preferred & Laptop \\
Brand & & \\
\end{tabular}} \\
\hline & $\begin{array}{l}\text { Sum of } \\
\text { Squares }\end{array}$ & $\mathrm{df}$ & $\begin{array}{l}\text { Mean } \\
\text { Square }\end{array}$ & $\mathrm{F}$ & Sig \\
\hline Between Groups & 16.669 & 4 & 4.1671 & 0.8772 & 0.48 \\
\hline Within Groups & 546.323 & 115 & 4.7506 & & \\
\hline Total & 562.992 & 119 & & & \\
\hline
\end{tabular}

Table 10 shows that the sig. value (p-value) (0.48) for audio quality is greater than Alfa value $(0.05)$. Audio quality seems important while we could have voice chart on laptop but most of respondents use mobile for voice calls and YouTube then its impact is not significant for brand preference of laptop.

\subsubsection{Brand Preferences of Laptop and Video Quality}

H0: nonexistence of significant association between brand preferences of laptop and video quality. Ha: existence of significant association between brand preferences of laptop and video quality.

Table 11: Brand preferences of laptop and video quality

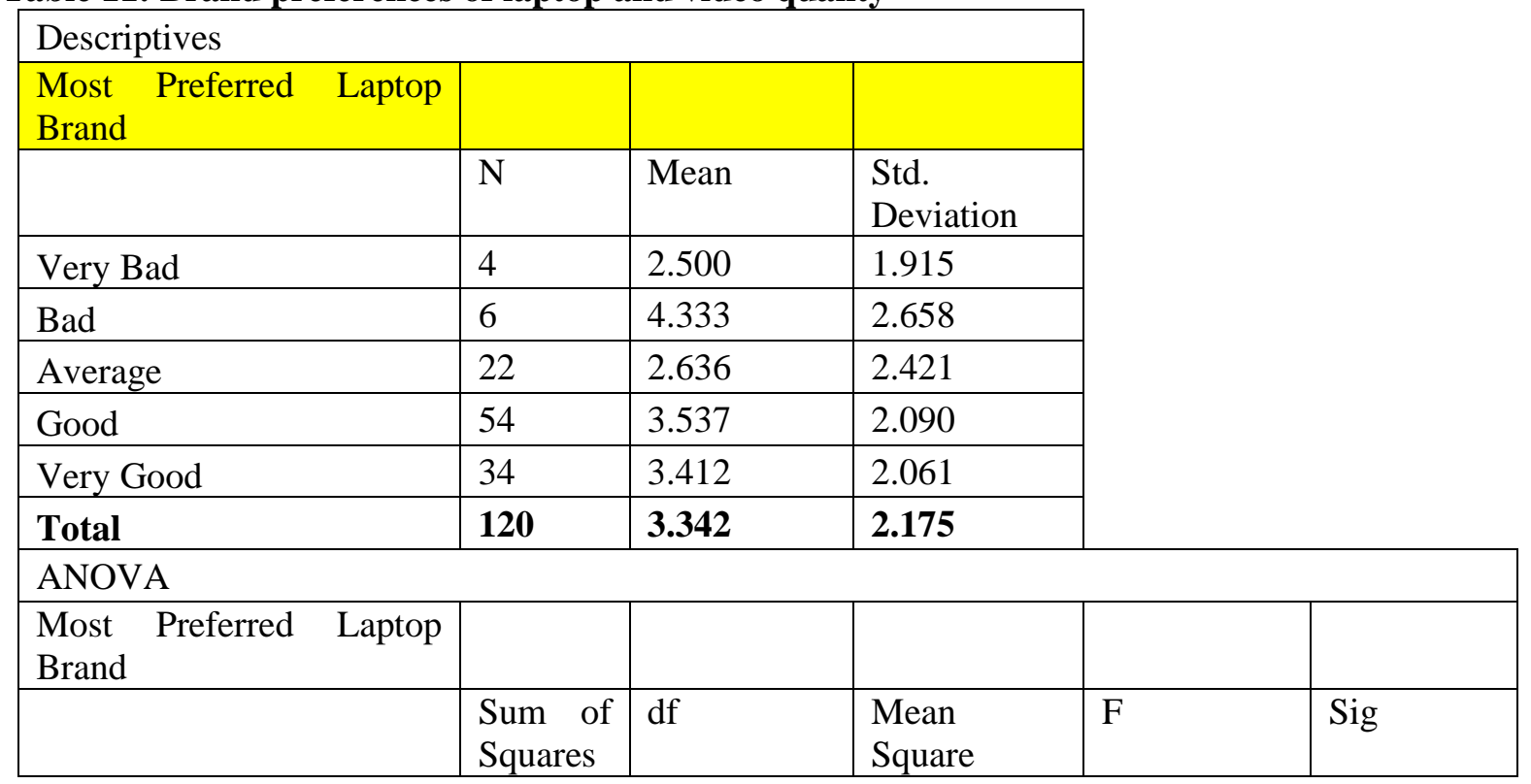




\begin{tabular}{|l|l|l|l|l|l|} 
Between Groups & 21.906 & 4 & 5.477 & 1.164 & 0.330 \\
\hline Within Groups & 541.085 & 115 & 4.705 & & \\
\hline Total & $\mathbf{5 6 2 . 9 9 2}$ & $\mathbf{1 1 9}$ & & & \\
\hline
\end{tabular}

Table 11 shows that the sig. value (p-value) (0.330) for video quality is greater than Alfa value $(0.05)$. In this way video quality has not much impact on brand preference of laptop as mobile and tabs are found to be used for video purpose as by sleeping user view it.

\subsection{Economics Attraction for Brand Preferences:}

The purchasing power is main determinants so, it is important to assess using price, after sales service and economics attractions impact on brand preference of laptop.

\subsubsection{Brand Preferences of Laptop and Price}

H0: nonexistence of significant association between brand preferences of laptop and price.

Ha: existence of significant association between brand preferences of laptop and price.

Table 12: Relationship between brand preferences of laptop and price

\begin{tabular}{|c|c|c|c|c|c|}
\hline \multirow{2}{*}{\multicolumn{4}{|c|}{ Descriptive }} & & \\
\hline & & & & & \\
\hline \multicolumn{4}{|l|}{$\begin{array}{lll}\text { Most } & \text { Preferred } & \text { Laptop } \\
\text { Brand } & & \end{array}$} & & \\
\hline & $\mathrm{N}$ & Mean & $\begin{array}{l}\text { Std. } \\
\text { Deviation }\end{array}$ & & \\
\hline Very Bad & 1 & 1 & . & & \\
\hline $\mathrm{Bad}$ & 11 & 3.364 & 1.912 & & \\
\hline Average & 44 & 3.364 & 2.334 & & \\
\hline Good & 46 & 3.370 & 2.184 & & \\
\hline Very Good & 18 & 3.333 & 2.058 & & \\
\hline Total & 120 & 3.342 & 2.175 & & \\
\hline \multicolumn{6}{|l|}{ ANOVA } \\
\hline \multicolumn{6}{|l|}{\begin{tabular}{lll|} 
Most & Preferred & Laptop \\
Brand & & \\
\end{tabular}} \\
\hline & $\begin{array}{l}\text { Sum of } \\
\text { Squares }\end{array}$ & df & $\begin{array}{l}\text { Mean } \\
\text { Square }\end{array}$ & $\mathrm{F}$ & Sig \\
\hline Between Groups & 5.547003 & 4 & 1.387 & 0.286 & 0.886 \\
\hline Within Groups & 557.4447 & 115 & 4.847 & & \\
\hline Total & 562.9917 & 119 & & & \\
\hline
\end{tabular}

Table 12 shows that the sig. value (p-value) (0.886) for price is greater than Alfa value $(0.05)$. surprisingly price also could not make significance position for laptop brand preference and during KII, it was accepted by saying laptop is not luxury but necessity of professional so they prefer on the basis of user-friendliness rather than accepting brands of choice. Just compromise their choice to avoid risk of being unfriendly.

\subsubsection{Brand Preferences of Laptop and Convenience of Service}

H0: nonexistence of significant association between brand preferences of laptop and convenience of service.

Ha: existence of significant association between brand preferences of laptop and convenience of service.

Table 13: Brand preferences and convenience of service

\begin{tabular}{|l|l|l|l|}
\hline Descriptives \\
\hline $\begin{array}{l}\text { Most Preferred Laptop } \\
\text { Brand }\end{array}$ & & & \\
\hline
\end{tabular}




\begin{tabular}{|l|l|l|l|} 
Convenience of Service & N & Mean & $\begin{array}{l}\text { Std. } \\
\text { Deviation }\end{array}$ \\
\hline Very Bad & 11 & 3.364 & 1.912 \\
\hline Bad & 12 & 2.833 & 1.992 \\
\hline Average & 23 & 3.870 & 2.616 \\
\hline Good & 52 & 3.346 & 2.123 \\
\hline Very Good & 22 & 3.045 & 2.081 \\
\hline Total & $\mathbf{1 2 0}$ & $\mathbf{3 . 3 4 2}$ & $\mathbf{2 . 1 7 5}$ \\
\hline ANOVA
\end{tabular}

\begin{tabular}{|l|l|l|l|l|l|}
\hline ANOVA & & & & \\
\hline $\begin{array}{l}\text { Most Preferred Laptop } \\
\text { Brand }\end{array}$ & $\begin{array}{l}\text { Sum of } \\
\text { Squares }\end{array}$ & Df & $\begin{array}{l}\text { Mean } \\
\text { Square }\end{array}$ & F & Sig \\
\hline Between Groups & 11.447 & 4 & 2.8618 & 0.5967 & 0.666 \\
\hline Within Groups & 551.545 & 115 & 4.7960 & & \\
\hline Total & $\mathbf{5 6 2 . 9 9 2}$ & $\mathbf{1 1 9}$ & & & \\
\hline
\end{tabular}

Table 13 shows that the sig. value (p-value) (0.666) for convenience of service is greater than Alfa value (0.05). Convenience of service is important but buyer gave focus on their self-ability to use assuming laptop market as perfect market where service level of all suppliers is similar. These causes convince of service not significant for brand preferences.

\subsubsection{Brand Preferences of Laptop and Schemes and Offers}

H0: nonexistence of significant association between brand preferences of laptop and schemes and offers.

Ha: existence of significant association between brand preferences of laptop and schemes and offers.

Table 14: Schemes and offers Impact on Brand Preference

\begin{tabular}{|c|c|c|c|c|c|}
\hline \multirow{2}{*}{\multicolumn{4}{|c|}{ Descriptives }} & & \\
\hline & & & & & \\
\hline \multicolumn{4}{|l|}{$\begin{array}{l}\text { Most Preferred Laptop } \\
\text { Brand }\end{array}$} & & \\
\hline Schemes \& Offers & $\mathrm{N}$ & Mean & $\begin{array}{l}\text { Std. } \\
\text { Deviation }\end{array}$ & & \\
\hline Strongly Disagree & 2 & 3.000 & 2.828 & & \\
\hline Disagree & 8 & 2.250 & 1.832 & & \\
\hline Neutral & 38 & 3.737 & 2.049 & & \\
\hline Agree & 59 & 3.119 & 2.150 & & \\
\hline Strongly Agree & 13 & 3.923 & 2.660 & & \\
\hline Total & 120 & 3.342 & 2.175 & & \\
\hline \multicolumn{6}{|l|}{ ANOVA } \\
\hline \multicolumn{6}{|l|}{$\begin{array}{lll}\text { Most } & \text { Preferred } & \text { Laptop } \\
\text { Brand } & & \\
\end{array}$} \\
\hline & $\begin{array}{l}\text { Sum of } \\
\text { Squares }\end{array}$ & df & $\begin{array}{l}\text { Mean } \\
\text { Square }\end{array}$ & $\mathrm{F}$ & Sig \\
\hline Between Groups & 23.031 & 4 & 5.7577 & 1.2263 & 0.30 \\
\hline Within Groups & 539.961 & 115 & 4.6953 & & \\
\hline Total & 562.992 & 119 & & & \\
\hline
\end{tabular}

Table 14 shows that the sig. value (p-value) (0.304) for schemes and offers is greater than Alfa value (0.05). Schemes and offers are not signifying its impact as they focus on performance suitability of laptop with user suitability.

\subsubsection{Brand Preferences of Laptop and Advertisement}


H0: nonexistence of significant association between brand preferences of laptop and advertisement. Ha: existence of significant association between brand preferences of laptop and advertisement.

Table 15: Brand preferences of laptop and advertisement

\begin{tabular}{|c|c|c|c|c|c|}
\hline \multirow{2}{*}{\multicolumn{4}{|c|}{ Descriptives }} & & \\
\hline & & & & & \\
\hline \multicolumn{4}{|l|}{$\begin{array}{l}\text { Most Preferred Laptop } \\
\text { Brand }\end{array}$} & & \\
\hline Advertisement & $\mathrm{N}$ & Mean & $\begin{array}{l}\text { Std. } \\
\text { Deviation }\end{array}$ & & \\
\hline Strongly Disagree & 6 & 2.500 & 2.345 & & \\
\hline Disagree & 4 & 5.500 & 3.416 & & \\
\hline Neutral & 32 & 3.094 & 2.022 & & \\
\hline Agree & 54 & 3.296 & 2.177 & & \\
\hline Strongly Agree & 24 & 3.625 & 2.039 & & \\
\hline Total & 120 & 3.342 & 2.175 & & \\
\hline \multicolumn{6}{|l|}{ ANOVA } \\
\hline \multicolumn{6}{|l|}{$\begin{array}{lll}\text { Most } & \text { Preferred } & \text { Laptop } \\
\text { Brand } & & \\
\end{array}$} \\
\hline & $\begin{array}{l}\text { Sum of } \\
\text { Squares }\end{array}$ & Df & $\begin{array}{l}\text { Mean } \\
\text { Square }\end{array}$ & $\mathrm{F}$ & Sig \\
\hline Between Groups & 26.889 & 4 & 6.722 & 1.442 & 0.225 \\
\hline Within Groups & 536.103 & 115 & 4.662 & & \\
\hline Total & 562.992 & 119 & & & \\
\hline
\end{tabular}

Table 15 shows that the sig. value (p-value) (0.225) for advertisement is greater than Alfa value (0.05). Advertisement does not signify as buyers are professional and believe fitness of use is best to meet their need which comes from customize talks not general advertisement.

\subsubsection{Brand preferences of laptop and friend $\&$ family influence}

H0: nonexistence of significant association between brand preferences of laptop and friend \& family influence.

Ha: existence of significant association between brand preferences of laptop and friend \& family influence.

Table 16: Friend and family influence on Brand Preference

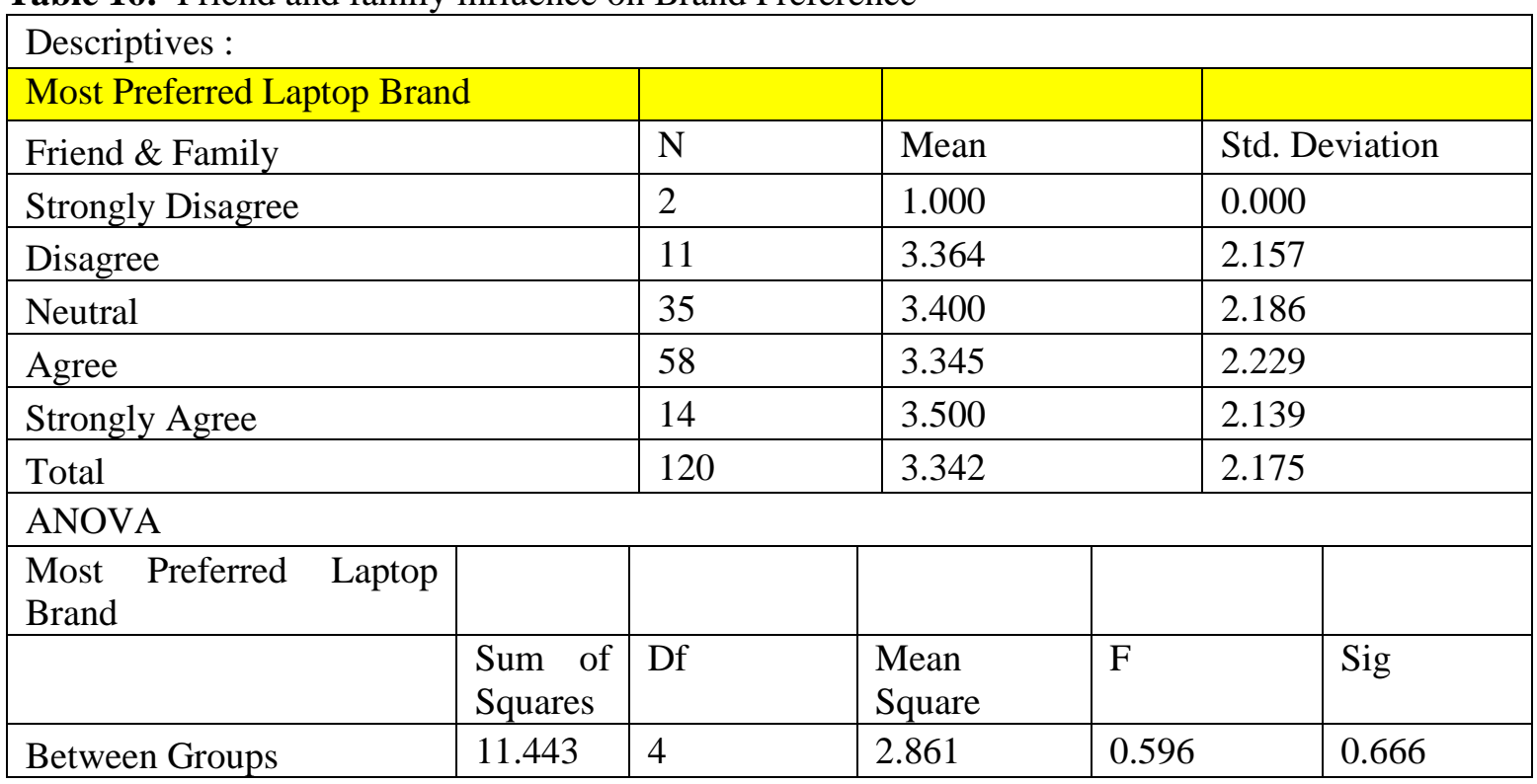




\begin{tabular}{|l|l|l|l|l|l|} 
Within Groups & 551.549 & 115 & 4.796 & & \\
\hline Total & 562.992 & 119 & & & \\
\hline
\end{tabular}

Table 16 shows that the sig. value (p-value) (0.666) for friend and family influence is greater than Alfa value (0.05). Friend \& family influence brand preference [9] but only those who perform the same where there is competition and they do not trust on each other's whereas from other they do not get influenced as they think purpose are different. This causes friends and family to be ineffective influencer.

\subsubsection{Brand Preferences of Laptop and add-on software Packages}

H0: nonexistence of significant association between brand preferences of laptop and add-on software packages.

Ha: existence of significant association between brand preferences of laptop and add-on software packages.

Table 17: Relationship between brand preferences of laptop and add-on software packages

\begin{tabular}{|l|l|l|l|}
\hline Descriptive & & \\
\hline $\begin{array}{l}\text { Most Preferred Laptop } \\
\text { Brand }\end{array}$ & $\mathrm{N}$ & Mean & $\begin{array}{l}\text { Std. } \\
\text { Deviation }\end{array}$ \\
\hline Add on Software packages & & & 2.309 \\
\hline Strongly Disagree & 3 & 3.667 & 2.360 \\
\hline Disagree & 7 & 3.714 & 2.027 \\
\hline Neutral & 14 & 3.429 & 2.149 \\
\hline Agree & 60 & 3.300 & 2.337 \\
\hline Strongly Agree & 36 & 3.278 & $\mathbf{2 . 1 7 5}$ \\
\hline Total & $\mathbf{1 2 0}$ & $\mathbf{3 . 3 4 2}$ & \\
\hline
\end{tabular}

\begin{tabular}{|l|l|l|l|l|l|}
\hline ANOVA & & & & \\
\hline $\begin{array}{l}\text { Most Preferred Laptop } \\
\text { Brand }\end{array}$ & $\begin{array}{l}\text { Sum of } \\
\text { Squares }\end{array}$ & Df & $\begin{array}{l}\text { Mean } \\
\text { Square }\end{array}$ & F & Sig \\
\hline Between Groups & 1.646 & 4 & 0.4114 & 0.0843 & 0.987 \\
\hline Within Groups & 561.346 & 115 & 4.8813 & & \\
\hline Total & $\mathbf{5 6 2 . 9 9 2}$ & $\mathbf{1 1 9}$ & & & \\
\hline
\end{tabular}

Source: Mishra and Aithal [1]

Table 17 shows that the sig. value (p-value) (0.6030) for add-on software packages is greater than Alfa value (0.05). Nonexistence of significant association between brand preference of laptop and add-on software packages was found as buyers assume software essential are there and we do not need extra because excel and words are all brands which they use most of cases.

\subsubsection{Brand Preferences and Extended Service Warranty}

H0: nonexistence of significant association between brand preferences of laptop and extended service warranty.

Ha: existence of significant association between brand preferences of laptop and extended service warranty.

Table 18: Brand preferences and extended service warranty

\begin{tabular}{|l|l|l|l|}
\hline Descriptive: \\
\hline $\begin{array}{l}\text { Most Preferred Laptop } \\
\text { Brand }\end{array}$ & & & \\
\hline
\end{tabular}




\begin{tabular}{|c|c|c|c|c|c|}
\hline $\begin{array}{l}\text { Extended } \\
\text { warranty }\end{array}$ & $\mathrm{N}$ & Mean & $\begin{array}{l}\text { Std. } \\
\text { Deviation }\end{array}$ & & \\
\hline Strongly Disagree & 3 & 4.333 & 3.055 & & \\
\hline Disagree & 6 & 3.333 & 1.966 & & \\
\hline Neutral & 21 & 3.095 & 2.071 & & \\
\hline Agree & 39 & 3.462 & 2.101 & & \\
\hline Strongly Agree & 51 & 3.294 & 2.309 & & \\
\hline Total & 120 & 3.342 & 2.175 & & \\
\hline \multicolumn{6}{|l|}{ ANOVA } \\
\hline \multicolumn{6}{|l|}{$\begin{array}{l}\text { Most Preferred Laptop } \\
\text { Brand }\end{array}$} \\
\hline & $\begin{array}{l}\text { Sum of } \\
\text { Squares }\end{array}$ & Df & $\begin{array}{l}\text { Mean } \\
\text { Square }\end{array}$ & $\mathrm{F}$ & Sig \\
\hline Between Groups & 4.902 & 4 & 1.2254 & 0.2525 & 0.9080 \\
\hline Within Groups & 558.090 & 115 & 4.8530 & & \\
\hline Total & 562.992 & 119 & & & \\
\hline
\end{tabular}

Table 18 shows that the sig. value (p-value) (0.9080) for extended service warranty is greater than Alfa value (0.05). Nonexistence of a significant association between the brand preference of laptop and extended service warranty as its standard of design which is same for all and its different might have been adjusted with price difference as nothing is free.

\section{CONCLUSION :}

The age of buyers does not significantly impact on brand preference of laptops at less than $10 \%$ significance level as $10 \%$ level of significance age becomes effective determinates of brand preference. Monthly income plays an important role in brand preference of laptops as monthly income determines the ability to buy and need for work to be performed by the laptop. Brand preference of laptop not much depend on educational qualification, brand image, features, configuration, audio quality, video quality, price, convenience of service, scheme and offers, advertisement, family and friend influence as monthly income address all issues of needs and preference in case of laptops irrespective of other products. The hypothesis testing showed that the brand preference has significant relationship only with occupation, age and monthly income. It is important for marketing planner to segment laptop consumers on the basis of occupation, monthly income and age rather than educational qualification, brand image, features, configuration, audio quality, video quality, price, convenience of service, scheme and offers, advertisement, family, and friend influence. It shows specific products need to be analyzed on specific buyer influencing factors.

\section{REFERENCES :}

[1] Mishra, A. K., \& Aithal, P. S. (2021). Factors and Features Influencing Laptop Users of Kathmandu, Nepal. International Journal of Case Studies in Business, IT, and Education (IJCSBE), 5(1), 132142.

[2] Sah, S., \& Mishra., A. K. (2020). Consumers' Brand Preference of Laptop in Kathmandu, Nepal. NOLEGEIN Journal of Consumer Behavior \& Market Research, 3(2), 7-23.

[3] Mishra. A.K., (2019). Influential Marketing Strategies Adopted by the Cement Industries. International Journal of Research-Granthaalayah, 7(10), 155-173.

[4] Mishra, A. K., Sharestha, B. (2019). Assessment of Consumer Influencing Factor in Decision Making for Selecting Cement Brands. South Asain Res J Bus Mgmt, 1(3), 91-105.

[5] Kotler, P., \& Armstrong, G. (2010). Principles of Marketing. India: Pearson Education.

[6] Kotler, P., \& Keller, K. L. (2011). Marketing Management \& Interpretive Simulations Access Code Card Group B Package (14 ed.). Pearson Education. 
[7] Kotler, P. (2013). Marketing Management: Analysis, Planning, Implementing and Control (1st ed.). India: Pearson Education.

[8] Mishra. A. K. (2020). Global Contract Administration. (p. 145). Tamilnadu: D. K. International Research Foundation. ISBN: 978-81-945468-3-2, DOI: http://doi.org/10.5281/zenodo.4817527.

[9] Heryanto, H. (2011). Effect of Marketing Strategy on Customer Loyalty Bajapuik Savings at PT. International Journal of Lean Thinking, 2(1), 59-87. 